\title{
I'm 10 registered. What should I do?
}

\section{The GDC explains.}

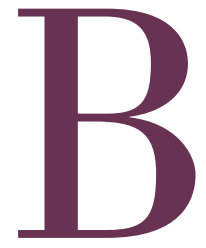

efore 31 July 2008, dental nurses and dental technicians had a one-off opportunity to register with the GDC on the basis of their experience or with an old-style qualification. Now that these transitional arrangements for registration have come to an end, the only way on to the Dental Care Professionals Register is with a GDC-recognised qualification.
But what does this mean for you and your employer if you haven't yet registered and your qualification is no longer recognised or you have not undergone formal, approved training?

This article outlines exactly which qualifications continue to be registrable, and which ones don't. It also explains what steps to take next if your route to registration is closed, and who to contact for more information.
Dental nurses:

is your qualification registrable?

If your qualification has been approved by the GDC, you will still be able to register on the basis of that qualification.

Details of registrable qualifications are listed below, as well as those that are no longer recognised for registration:

\section{Dental nurses}

UK qualifications

These qualifications continue to be recognised for registration after the 30 July deadline

\section{Qualification}

\section{Awarded by}

\begin{tabular}{|c|c|c|}
\hline \multirow{5}{*}{$\begin{array}{l}\text { These qualifications continue to } \\
\text { be recognised for registration } \\
\text { after the } 30 \text { July deadline }\end{array}$} & National Certificate in Dental Nursing & $\begin{array}{l}\text { National Examining Board for Dental } \\
\text { Nurses (NEBDN) }\end{array}$ \\
\hline & NVQ/VRQ in Oral Healthcare Level 3 & City \& Guilds \\
\hline & SVQ in Oral Healthcare Level 3 & Scottish Qualifications Authority \\
\hline & Dental Hospital Certificate of Proficiency in Dental Nursing & $\begin{array}{l}\text { Dental hospitals recognised by the } \\
\text { Association of Dental Hospitals }\end{array}$ \\
\hline & $\begin{array}{l}\text { Certificate of Higher Education in Dental Nursing } \\
-1 \text { year programme }\end{array}$ & $\begin{array}{l}\text { The University of Portsmouth and } \\
\text { Cardiff University }\end{array}$ \\
\hline \multicolumn{3}{|l|}{$\begin{array}{l}\text { Qualifications no } \\
\text { longer awarded }\end{array}$} \\
\hline \multirow{8}{*}{$\begin{array}{l}\text { The following qualifications } \\
\text { are no longer recognised } \\
\text { for registration after the } \\
30 \text { July deadline }\end{array}$} & National Certificate & $\begin{array}{l}\text { National Examining Board for Dental } \\
\text { Surgery Assistants (NEBDSA) }\end{array}$ \\
\hline & Certificate of Proficiency in Dental Surgery Assisting & $\begin{array}{l}\text { Dental hospitals recognised by the } \\
\text { Association of Dental Hospitals }\end{array}$ \\
\hline & $\begin{array}{l}\text { National Certificate in Science (Dental Surgery Assisting } \\
\text { or Dental Nursing) }\end{array}$ & BTEC \\
\hline & Certificate in Dental Surgery Assisting or Dental Nursing & SCOTVEC \\
\hline & Part III DSA Training (Certified) & Royal Navy \\
\hline & Class 2 Dental Clerk Assistant & Army \\
\hline & DSA Training and Trade Ability Test & Royal Air Force \\
\hline & Basic Dental Nurse Training and Individual Development & Defence Dental Agency \\
\hline Accreditation & Membership of the Voluntary National Register & British Association of Dental Nurses \\
\hline
\end{tabular}




\section{Dental technicians}

Qualification

Awarded by

UK qualifications

These qualifications continue to be recognised for registration after the 30 July deadline

\begin{tabular}{|l|l|}
\hline BTEC National Diploma Dental Technology & Approved BTEC providers \\
\hline SQA Higher National Certificate in Dental Technology & Approved SQA providers \\
\hline BSC in Dental Technology & $\begin{array}{l}\text { Manchester Metropolitan University } \\
\text { and University of Wales Institute, } \\
\text { Cardiff }\end{array}$ \\
\hline Foundation Degree in Dental Technology & $\begin{array}{l}\text { De Montfort University, University } \\
\text { of Wales Institute, Cardiff and } \\
\text { Manchester Metropolitan University }\end{array}$ \\
\hline Diploma in Dental Technology & University of Leeds \\
\hline
\end{tabular}

Qualifications no

longer awarded

\begin{tabular}{|l|l|l|}
\hline \multirow{2}{*}{$\begin{array}{l}\text { The following qualifications } \\
\text { are no longer recognised } \\
\text { for registration after the } \\
30 \text { July deadline }\end{array}$} & City and Guilds Final Certificate in Dental Technology & \\
\cline { 2 - 3 } & BTEC Diploma in Dental Technology & SCOTVEC Higher National Certificate in Dental Technology \\
\cline { 2 - 3 } & $\begin{array}{l}\text { Edexcel BTEC Higher National Certificate } \\
\text { Army - Levels 1, 2 and 3 (Dental Technology) }\end{array}$ & \\
\hline & $\begin{array}{l}\text { Qualifications awarded by Technicians Education Council } \\
\text { or Scottish Technicians Education Council }\end{array}$ & $\begin{array}{l}\text { Manchester Metropolitan University } \\
\text { and University of Wales Institute, } \\
\text { Cardiff }\end{array}$ \\
\hline Accreditation & $\begin{array}{l}\text { Membership of the Voluntary National Register } \\
\text { Aental Technicians Association }\end{array}$ \\
\hline
\end{tabular}

\section{Dental technicians: is your qualification registrable?}

If your qualification has been approved by the GDC, you will still be able to register on the basis of that qualification. Details of registrable qualifications are listed above as well as those that are no longer recognised for registration.

\section{What do I do if my qualification is no longer recognised?}

If you have a qualification that is no longer awarded or recognised by the GDC, and you have not yet registered, you will need to join a training course as soon as possible. Trainee dental nurses and dental technicians who are working towards a registrable qualification don't need to register with us until they have finished their studies. However, please remember that you will need to register as soon as you have qualified.

\section{How can I find out if there is a training course in my area?}

A full list of training course providers in dental nursing and dental technology is available below. You will need to contact the course provider directly to find out entry requirements and availability.

\section{Dental nursing}

The National Examining Board for Dental Nurses (NEBDN) awards the National Certificate in Dental Nursing. Details of UK study and examination centres are available from: NEBDN, 110 London Street, Fleetwood, Lancashire, FY7 6EU

Phone: 01253778 417, Email: info@nebdn. org.uk, Web: www.nebdn.org.uk

The NVQ/VRQ is awarded by City \& Guilds. Details of study and examination centres in England and Wales are available from: Customer Service, City \& Guilds Care, Health \& Community, 1 Giltspur Street, London, EC1A 9DD

Phone: 0207294 2800, Web: www.city-andguilds.co.uk

Further information on the Certificate of Higher Education in Dental Nursing is available from: University of Portsmouth, School of Professionals Complementary to
Dentistry, Science Admission Centre, Science Faculty Office, St Michael's Building, White Swan Road, Portsmouth, PO1 2DT Phone: 02392845 550, Email: sci.admissions@ port.ac.uk, Web: www.port.ac.uk/teeth

Cardiff University, School of Postgraduate Medical and Dental Education, Grove Mews, 1 Coronation Road, Birchgrove, Cardiff, CF14 4XY

Phone: 02920544 989, Email: jackmanjc@ cardiff.ac.uk, Web: www.dentpostgradwales. ac.uk

Details of study and examination centres in Scotland for the SVQ Oral Health Care: Dental Nursing Level 3 are available from: Scottish Qualifications Authority, The Optima Building, 58 Robertson Street, Glasgow, G2 8DQ Phone: 0845279 1000, Web: www.sqa.org.uk

Dental technology

The following colleges offer dental technology courses: 
Belfast School of Dental Technology, School of Dentistry, Royal Group of Hospitals, Grosvenor Road, Belfast, BT12 6BP Phone: 02890632 733/4, Email: patrick. mcelwee@royalhospitals.n-i.nhs.uk, Web: www.qub.ac.uk/cd

Matthew Boulton College ${ }^{\star}$, Centre for Dental Technology, Sherlock Street, Birmingham, B5 7DB

Phone: 01214464545 ext 3270, Email: ask@ matthewboulton.ac.uk, Web: www.matthewboulton.ac.uk

University of Wales Institute, School of Health and Social Sciences, Llandaff Campus, UWIC, Western Avenue, Llandaff, Cardiff, CF5 2YB

Phone: 02920416 899, Web: www.uwic.ac.uk

Edinburgh's Telford College $^{\star \star}$, Customer Services, 350 West Granton Road, Edinburgh, EH5 1QE

Phone: 01315594000

School of Dental Technology, Learning and Teaching Office, Leeds Dental Institute, Clarendon Way, Leeds, LS2 9LU

Phone: 0113343 6199, Email: dentistry@leeds. ac.uk, Web: www.leeds.ac.uk/dental

City of Liverpool Community College*, Vauxhall Road, Liverpool, L3 6BN Phone: 0151252 4833, Email: chris.fielding@ liv-coll.ac.uk, Web: www.liv-coll.ac.uk

Lambeth College ${ }^{\star}$, School of Applied Sciences, 45 Clapham Common Southside, London, SW4 9BL

Phone: 0207501 5824, Email: courses@ lambethcollege.ac.uk, Web: www. lambethcollege.ac.uk

Manchester Metropolitan University, Centre for Dental Technology Studies, School of Biology, Chemistry and Health Science, Chester Street, Manchester, M1 5GD Phone: 0161247 3346, Web: www.sci-eng. mmu.ac.uk/bchs

Castle College, Nottingham ${ }^{\star}$, Centre for Dental Technology, Maid Marian Way, Nottingham, NG1 6AB

Phone: 0845845 0500, Email: learn@ castlecollege.ac.uk, Web: www.castlecollege. ac.uk

The Sheffield College, Castle Centre, Southside, Granville Road, Sheffield, S2 2RL Phone: 0114260 2600, Email: mail@sheffcol. ac.uk, Web: www.sheffcol.ac.uk
*The Birmingham, Liverpool, London and Nottingham colleges offer a Foundation Degree Dental Technology programme. This programme is awarded by De Montfort University.

${ }^{*}$ The programme at Telford College has not yet been approved by the GDC as a registrable qualification.

\section{How can I be sure that I'm classed as 'in training'?}

Dental nurses and dental technicians are in training' if they are:

- Employed by a practice or laboratory and enrolled on a training course leading to registration which has yet to start; or

- Employed by a practice or laboratory with a view to enrolling on a training course for which enrolment has not yet opened.

If either of these statements apply to you, you are classed as a student dental nurse or student dental technician and don't need to register with us until you have finished your studies. However, please remember that you will need to register as soon as you have qualified.

\section{What are the guidelines for student dental nurses and student dental technicians 'in training'?}

If you work in the practice or laboratory as a student dental nurse or student dental technician before formal training can begin, you should have a proper induction covering health and safety and confidentiality. You should also keep a log of the training you receive in the practice or laboratory, and have any necessary immunisations.

\section{What if I am unable to get onto a training course?}

You should make every effort possible, and be able to demonstrate that you have made every effort, to get on to the next available course. If necessary, you should get onto a waiting list and request a letter that states you are on the waiting list. If you are working in the practice or laboratory before formal training begins, you should have a proper induction covering health and safety and confidentiality. You should also have the necessary immunisations and keep a log of the training you receive in the practice or laboratory while waiting to start the course.

However, if the subject moves to individuals with no intention of registering, it is important to remember that it is the titles of 'dental nurse' and 'dental technician' which are protected in law. If you are not registered, then continuing to call yourself a dental nurse or dental technician after 30 July 2008 is illegal, and you will risk prosecution if there is evidence of illegally using a protected title.

\section{My colleagues aren't registered. What should I do?}

All dental nurses and dental technicians you work with must now be registered with the GDC. Registrants should be aware that there are serious consequences for employing or commissioning work from unregistered dental nurses and dental technicians. If you are a registered dentist or dental care professional and you employ or manage an unregistered person to work as a dental nurse or dental technician (whatever job title you give them), you will be liable to fitness to practise proceedings, and possible erasure from the register. And if the actions of an unregistered worker cause harm, you will be responsible for their mistakes.

If your dental nurse or dental technician is 'in training', and working towards a registrable qualification, they don't need to register with us until they have finished their studies. If this is the case, as a team leader or manager you are responsible for ensuring that student dental nurses or student dental technicians have the appropriate training and vaccinations and that they are enrolled on a GDC-approved training programme.

\section{What are the requirements for inductions of students?}

Before student dental nurses and student dental technicians undertake any duties in the practice or laboratory, they must receive a comprehensive induction. This must include health and safety and confidentiality. You should also make sure that they keep a record of the training they receive in the practice or laboratory, and that they have the necessary immunisations, if appropriate. Please note that student dental nurses should not carry out exposure prone procedures until immunisations are complete.

Additionally, a named supervising registrant must take responsibility for supervising a student dental technician. By undertaking this responsibility, the supervising registrant agrees to be accountable for the work of the student dental technician.

\section{If you have any further questions regarding} registration or need advice on what to do next, please contact the GDC's Registration Team on 08453007794 or email GDCregistration@ gdc-uk.org.

This article was originally published in the GDC Gazette, summer 2008 issue. 